\title{
The Renege Case
}

Tom Brady, University of Dayton, USA

Ron Burrows, University of Dayton, USA

Mike Geary, University of Dayton, USA

\begin{abstract}
Schools of Business, Accounting Programs, the AACSB accreditation standards, the accounting profession and society demand that we require ethical behavior and actions from our students, faculty and administration. Therefore, accounting departments desire to integrate into their programs a serious attempt to help students develop the skills and judgment with which to analyze situations and make ethical decisions.
\end{abstract}

Key Objective: Consider the importance of ethics and integrity with regard to commitments made during the recruiting process including, specifically, reneging on employment offers that previously have been accepted.

\section{"The Importance of Ethics and Integrity in the Recruiting Process"}

Q

cott Miller had worked hard all his life (all twenty-two years of it) and now, seemingly, everything was coming together for him. In one month, May $17^{\text {th }}$, to be precise, he would graduate with honors from the five-year accounting program at Midwest University (MU). After traveling in Europe with a couple of old high school buddies, Scott was scheduled to start in his "dream job" on August 1st. For as long as he could remember Scott had wanted to be a CPA and he felt fortunate to have landed a position on the audit staff of the prestigious public accounting firm of Debits Credits and Moore (DCM). However, even though it looked like everything was going his way, Scott was not a happy young man as his college graduation approached. He was troubled because, for the first time in his life, he was not one hundred percent sure he knew what he wanted to do. He was having second thoughts about his decision to work for DCM and pursue a career in public accounting. In fact, he was seriously considering a different career path altogether.

Scott's father was a CPA and Scott entered MU committed to becoming a CPA himself and working for a big public accounting firm. He showed this interest early by becoming active in the accounting club and signing up for the five-year accounting program in his sophomore year.

Starting his junior year Scott was excited by the prospects of pledging Beta Alpha Psi (BAP) and interviewing for an internship position. His plan was to work during the second semester, the famous busy season, with a large CPA firm to get a good taste of his chosen profession. He was very disappointed when he didn't get an offer from any of the big firms he was interested in. Instead, he settled for an internship with a small local CPA firm. During his work term Scott did mostly tax work, which he found not very interesting, and a small amount of auditing, which he loved. Overall, the internship was a good experience and Scott favorably impressed the practicing CPAs he worked with. He knew he could do the work and was recommitted to doing public accounting with a large firm.

In his senior year Scott took MU's auditing class. His interest in public accounting combined with the brief auditing experience from his internship made this one of his favorite college classes. Scott was now one hundred and ten percent sure of his career path. Also in his senior year Scott became an officer in BAP. He was becoming a model student as evidenced by his sense of direction about his future, his very good grades, and his good relationships with the accounting faculty at MU.

Early in the first semester of his fifth year, Scott eagerly began interviewing for a full-time position for after graduation. With his college record he was in a position to be rather selective and he interviewed only with 
large public accounting firms. One in particular, DCM, impressed Scott during the interview process. Although he talked to all of the big firms and, although they all made offers to him, he decided early in the process that DCM was his "dream job." DCM gave him a very short acceptance period with their offer, but he didn't care. He accepted the offer with the plan to start work in August after his graduation.

In the first semester of his fifth year Scott took Advanced Auditing as one of his accounting electives. He loved the course and got even more fired up about his career plans. During the second semester Scott had another accounting elective to take. He chose Forensic Accounting. It too was very interesting. In fact, it was very, very interesting. This is where Scott's troubles began. With entry-level salaries hovering around $\$ 60,000$ and demand increasing nearly one hundred percent each year, it was easy for Scott to see why forensic accounting was the hottest and fastest growing area in accounting. Scott had always known he wanted to do auditing work. Now he started imagining how neat it would be to concentrate on fraud auditing and help companies detect and prevent fraud and white-collar crime, design anti-fraud programs and controls, meet regulatory requirements, and implement the corporate governance activities required by the Sarbanes-Oxley Act. Scott hoped that DCM offered opportunities in this field.

About half way through that semester BAP sponsored a speaker from CloserLook, the leading forensic accounting firm in the Midwest. Scott attended the session, not because it was required for his class, but because of his interest in the subject. The speaker, Laura Dawson, who graduated from MU only two years earlier, fascinated the audience with story after story about her experiences in fraud auditing at CloserLook. After the session, Scott approached Laura to thank her for the presentation and tell her how interesting her job sounded. She suggested that if he was interested in the work he should send a resume to CloserLook since they were always looking for good people. A week later, Scott got a letter from Laura asking again if he would like to send a resume. Since he had accepted a job with DCM he wasn't sure whether it was proper to send a resume to CloserLook. However, he was simply too intrigued by the idea of working in fraud auditing and he sent the resume. Two weeks later he got a letter from CloserLook inviting him to Chicago for an office interview. Now Scott was in a panic. He was really interested in CloserLook but he had committed to DCM. Not knowing what to do, he called Laura asking for advice. She told him that if he came for an office visit, he probably would get an offer of employment that same day. Scott neglected to tall Laura that he had accepted an offer from DCM.

\section{REQUIRED:}

Prepare a TYPED written analysis of this case. Use appropriate professional grammar, sentence structure, spelling, organization, and so on. Be specific.

We suggest that possible legal issues should generally be ignored in this discussion. We wish to concentrate on integrity and the ethical issues, and we likely do not have sufficient legal expertise. In general, employers often do not have grounds for legal action, decide not to pursue legal action, do not succeed with such action, or are awarded insignificant damages if successful.

As you consider the facts of this case it is suggested that you consider the role and importance of a person's "word," of a commitment, of trust, of ethics and integrity, in everyday life, business, and accounting in particular. What is the penalty or cost for "violations"? (Recent scandals, professional codes of ethics -e.g., AICPA, IMA, etc.-, and the increase in regulatory rules and enforcement -SOX, SEC, PCAOB, etc., could provide considerable material for such a discussion.)

In judging whether or not the decision to renege on an earlier employment acceptance is ethical, the facts of the case and the "conditions" surrounding the decision are typically of critical relevance. What are the key facts of this case? Explicit recognition of the various stakeholders is a critical element. Who are the primary, and secondary, stakeholders in this case and in similar employment situations? Upon considering the pertinent facts and identifying the various stakeholders it is appropriate to identify the dilemma posed by the case and ascertain what must be decided. It might be argued that some extenuating circumstances can justify a decision to renege. It is likely that you can identify some scenarios that seem clearly unethical, some that are clearly ethical, and many 
that are not totally clear. Consider the variations in circumstances that might surround an employment offer and acceptance and the related way in which the student and employer, and perhaps university Career Services office and major advisors, handle the entire recruiting process. The development of a code of conduct or ethics, not at all unusual in professional organizations or disciplines and at an increasing number of universities, might be considered for students, employers and possibly for Career Services (who would develop such a code and how might it be enforced?).

Attempt to distill from the different possibilities or scenarios (a) guidelines or a code of ethics that students should follow when making such decisions, (b) guidelines or a code of ethics for employers and (c) guidelines or a code that components of a university (Accounting Departments, Career Services, Student Advising, etc.) should follow under varying relevant circumstances.

\section{RENEGE CASE}

\section{TEACHING NOTES \& VARIATIONS IN CIRCUMSTANCES}

Note that many faculty \& academic units have reported having experiences with similar situations where students reneged on previously accepted offers for professional experience (i.e., internship) and permanent employment positions with one employer in order to accept an offer from another employer.

It is a very real question of significance for students, faculty, and employers.

In the "renege" case, the STAKEHOLDERS likely could include the following:

1. The student who has reneged, or is considering reneging, on a job acceptance.

2. Students who might have been considered by the first employer for the position if recruiting for it had not closed with the other student's acceptance.

3. Future students at MU who may/will not be recruited as heavily by this or other employers IF it is concluded that the students in the program are unethical or cannot be counted on to keep their employment commitment.

4. The employer who often has/or will incur significant recruiting costs and might not be able to hire a replacement on a timely basis and as a result be understaffed.

5. Other employees of the firm who may now have to pick up additional work (possibly harming the quality of their lives).

6. The clients of the employer who might not receive service of the same quality or be delayed in the receipt of such services.

7. The recruiting staff of the employer.

8. Other MU alumni who work with the employer.

9. Faculty and staff in the MU accounting department (the relationship between the department and employers/alumni, which is critical, may be adversely impacted).

10. The university or accounting department might see a drop in critical donations that support the program or scholarships, or even a drop in enrollment if placement success drops.

11. The student's family and friends.

Variations in circumstances such as the following might be suggested as relevant:

1. TIME BETWEEN DATE OF OFFER ACCEPTANCE AND REPORT TO WORK DATE:

The length of time between acceptance of an offer and the intended report date can vary from a few weeks to well over two years. Students often accept employment offers after a third year internship with the report date not until the Fall following a fifth year; at the other extreme perhaps, a student graduating in December might accept an offer in December with a start date the following January. 
2. STUDENT EITHER GOES INACTIVE OR REMAINS ACTIVE IN THE RECRUITING PROCESS:

Students typically remove themselves from the recruiting process upon accepting an offer, but some students have remained very active in the recruiting market (i.e., seeking other offers) even after formally accepting a job offer. The second employer might, or might not, know the student had accepted another offer.

3. TIME BETWEEN RENEGE AND REPORT TO WORK DATES:

The time remaining between the date the first employer is informed of the decision to renege and the intended report date, and the time that employer has to rectify this loss, might be of relevance. A student might inform the first employer that he/she will not be keeping the commitment well in advance of the scheduled report date, or the notification might come immediately before the report date (or even shortly after the report date). Perhaps the relevant question might be whether notification comes before or after completion of the relevant recruiting process for the employer (generally the end of the calendar year for a public accounting firm).

4. $\quad$ SUPPLY OF AND DEMAND FOR QUALIFIED RECRUITS:

Industry practice or the supply-demand situation with regard to qualified candidates might have a huge impact on the employer. For example, public accounting firms typically consider it important to complete the hiring process before the end of the year and thus before the beginning of the "busy period" audit and tax season. Thus, replacing a "no show" new hire at that last minute might prove difficult or impossible if there is a shortage of qualified candidates.

5. TIME ALLOWED FOR ACCEPTANCE OR REJECTION OF INITIAL OFFER:

The first employer might have been overly aggressive in prodding the student to accept the offer. The employer might not have given adequate time for the student to consider the offer and possible competing offers, and perhaps such things as finding out about housing availability and similar things in a particular city.

6. LACK OF CLARITY DURING INITIAL RECRUITMENT DISCUSSIONS:

The employer might not have provided a sufficiently clear picture of the firm and the job specifications or the requirements and benefits of the position offered.

7. ACCEPTED JOB BECAUSE AFRAID OF NOT GETTING DESIRED OFFER:

The student might be extremely interested in a career in a particular industry or location, or even with a specific "dream opportunity" employer with which they have been negotiating, but they do not have an offer in hand when a decent offer from another employer is about to an expire with no extension of time given. After accepting such an offer, a better offer from the "dream" employer is received.

8. SIGNIFICANT CHANGES AT INITIAL EMPLOYER:

There might be major changes at the first employer such as a merger, closing of an office, departure of key employees, loss of a key client, etc.

9. SUBSEQUENT ACTIVITIES OF OR REVELATIONS ABOUT FIRST EMPLOYER:

The student might object to some of the business activities of the employer, or the employer's clients, that were unknown or did not exist when the employment offer was accepted. For example, a person with strong anti-abortion beliefs might be unwilling to work for a firm with a client that openly and actively supports abortions (especially if the student was going to be assigned to that client).

10. DON'T WANT TO WORK FOR FIRST EMPLOYER:

The student might have a second offer in hand, or even have accepted such an offer, at the time of notifying the initial employer, or the student might simply have decided to go back into the recruiting market because they have decided they definitely did not wish to work with the first employer.

11. EXTENT OF DIFFERENCES OR SIMILARITIES BETWEEN PROSPECTIVE EMPLOYERS: The second employers might be similar, or vary, in location, size, clients, industry, etc.

12. CHANGES IN STUDENT'S PERSONAL SITUATION:

The student's personal situation might be relevant and could vary considerably (e.g., an impending marriage, health issues, relocation of immediate family, etc.). The extent to which relevant circumstances are, or are not, within the control of the student often varies (e.g., major illness with a parent living in a different location and with siblings still at home VS good friends of the student deciding to locate in a different city). 


\section{CULTURAL CONSIDERATIONS:}

There could be cultural misunderstanding, especially if the student has recently moved to the U.S. The student might, or might not, have given the first employer the opportunity to respond to the student's concerns, questions, desire for a different office location, better financial offer, etc.

14. EMPLOYER WOULD TREAT EMPLOYEES THE SAME WAY:

Students might believe, or not believe, that an employer would renege on an offer to a student, or dismiss the student as an employee very quickly in spite of very good work, if the employer decides it must reduce its staff. This in turn could lead the student to believe that if employers would act in such a manner, it would not be unethical for them to act in a similar way that was harmful to the employer.

15. PREFERENCE FOR EMPLOYMENT IN AREA OF SECOND MAJOR:

The student might be enticed to accept an offer from an employer in a different industry by a faculty member in another academic department where the student is completing a second major.

16. BONUS OR ENTICEMENTS WITH SHORT EXPIRATIONS:

Employers might entice/reward students for a prompt acceptance by offering a significant bonus that will expire at some point in the future under terms that vary from a couple of weeks to a few months.

17. FAMILY PRESSURES:

A student's family or friends might bring varying levels of pressure to renege on an offer in one city in order to locate in another city. Parents, grandparents, and others might lack objectivity because they are so "close" to a student such that anything the student seems to want, and appears like it will make them happy, is "by definition" ethical and they thus support the student in a decision to renege.

18. COMPARISON OF TERMS OF FIRST \& SECOND OFFERS:

The second employer might offer a much higher beginning salary, bonus, faster advancement, etc.

19. WAS FIRST OFFER/ACCEPTANCE ORAL/WRITTEN?

Offers and/or acceptances might be oral or in writing.

Possible GUIDELINES OR PRINCIPLES OR CODE OF ETHICS might include such things as:

\section{Students:}

1. A student should not accept a job offer if he/she intends to stay active in the job market looking for employment with a different firm.

2. A student should inform an initial employer on a timely basis if he/she intends to reenter the job market or consider an alternative offer from another employer.

3. Before reneging on an accepted offer, a student should discuss the relevant issues with a representative of the initial employer and/or another knowledgeable party.

4. A student should give the initial employer the opportunity to match or counter the second employer's offer when such is reasonably possible (e.g., office location, salary, etc.) and the employers and offers are otherwise sufficiently comparable.

5. A student should disclose the acceptance of an earlier offer, unless the initial employer has already been informed of the decision to renege in an appropriate manner, when contacted by, or contacting, another potential employer.

6. Students should increasingly avoid reneging on a previous offer acceptance as the report date gets closer and closer (especially when past the time when an employer can realistically hire an adequately qualified replacement).

\section{Employers:}

7. Employers contacted by a student should ask if an offer of employment from another employer has already been accepted and, if so, should break off negotiations unless confident the student is progressing in an ethical manner.

8. Employers who initiate contact with a student should ask if a previous offer has already been accepted and, if so, should cease all attempts to hire the student and thus cause the student to renege on the previous acceptance. 
9. Employers should give students adequate time, without undue pressure, to evaluate offers.

10. Employers should make adequate efforts to describe accurately all critical aspects of the position offered the student, potential career path, the organization, etc.

11. Employers should, after an acceptance, remain in contact with students and keep them adequately informed of material changes in the organization, its clients, etc.

12. Employers, especially when they make permanent offers "early," should attempt to develop practices and policies that attempt to deal with potential "renege" issues and make sure that such policies \& practices are communicated to students.

13. Employers should allow students adequate time to complete a reasonable, typical number of interviews, plus have sufficient time to analyze not only the duties, benefits, etc. of the position offered, but also such things as housing availability and costs in the relevant location, and other similar "personal" issues.

\section{University Career Services, Faculty, Advisors, etc.}

14. Academic accounting departments should include a discussion of this and similar topics via courses and/or extracurricular activities.

15. Career Services should include a discussion of this issue in seminars for students.

16. Career Services should communicate appropriate practices and ethical standards to employers and students. Students and employers who do not abide by such standards or act in an ethical manner should not be allowed to use the facilities of Career Services, participate in internship programs, etc.

The material below is of potential applicability to this case and is distilled from various pronouncements, articles, etc. related to NACE - National Organization of Colleges and Employers (emphasis added). This material can be used as background and external supporting material when discussing the Renege Case. More information and details about the original sources are available at www.naceweb.org.

The timing of offers and acceptances is a market-driven issue, with different industries experiencing varying degrees of urgency to fill positions. NACE encourages practices reasonable and appropriate for both employers and students. Communication is key to these decisions, with regular contact between the employer and student vital from the point of offer to the start date.

- In a robust and fast-paced job market for graduates and interns, some employers attempt to mitigate the effects of job-market competition with practices, including requiring students to accept job offers within a short time frame. Experience shows the best employment decisions for both students and employers are those that are made without pressure and with the greatest amount of information. Students given sufficient time ... may be less likely to renege on job acceptances.

\section{Deliberation}

The NACE Principles Committee examined the issue based on NACE research, thoughts expressed by both career center and employer members, and discussion at the NACE 2008 Annual Conference. The primary basis for deliberation was the preamble to the Principles for Professional Conduct document that directs members to:

- Maintain an open and free selection of employment opportunities in an atmosphere conducive to objective thought, where job candidates can choose optimum long-term uses of their talents that are consistent with personal objectives and all relevant facts.

- Maintain a recruitment process that is fair and equitable to candidates and employing organizations.

- $\quad$ Support informed and responsible decision making by candidates.

\section{CONCLUSION}

The NACE Principles for Professional Conduct Committee understands that not all employers recruit at the same time of the year, nor do all colleges follow the same academic calendar. Therefore, recommending specific 
calendar dates for offers and acceptances would not be appropriate. Furthermore, many employers issue offers to their graduating co-ops or interns at the start of the employer's recruiting cycle in order to provide those students priority consideration prior to extending offers to other students. Finally, shorter decision time frames would be appropriate if the candidate's graduation date and start date are very close.

Employers should assess their use of offer deadlines to ensure they are not placing undue pressure on a student. Pressure can come not only from the deadline, but also the use of financial incentives (signing bonuses, increased salary, and so forth) encouraging very early acceptance of offers. Today's technology can significantly shorten the time from interview to receipt of complete job offer information. Although both students and employers benefit through this quick communication, it also can shorten the time available for students to make good decisions and increases the sense of urgency. Career centers should provide guidance to students to help them make informed decisions when accepting or not accepting job offers. Career centers may provide guidance to employers and recommend that they consider extending deadlines when needed. Students should also be sensitive to employer needs and accept offers in a reasonable time. Career centers can help students work with employers to determine what might be a reasonable time.

NACE and the Principles Committee do not advocate enforcing a specific time frame, but rather encourage practices reasonable and appropriate for both employers and students. The Principles Committee believes that providing sufficient time for students to evaluate the employment opportunities offered to them allows them to make the wisest decisions for all concerned, creating a positive experience for candidates and employers, and ultimately reducing renege and attrition rates. Employers are expected to provide prospects with a reasonable amount of time to make a decision about accepting an employment offer. What is considered "reasonable"? The answer will vary, given industry standards, a student's prior experience with the employer, offer timing, and how close it is to your graduation date/start time. It is reasonable to request - and receive-additional time to complete other scheduled interviews, so you can make the best decisions for your career and for your future employer.

\section{It also is improper for employers to pressure anyone to revoke their acceptance of another job offer.}

When employment professionals conduct recruitment activities through student associations or academic departments, such activities will be conducted in accordance with the policies of the career services office. Employers also are expected to provide job candidates with a reasonable process for making your decision. (An example of an unreasonable process is one in which the student is told the offer is good for a set amount of time; however, the same offer has been made to others, and the student who accepts first gets the job.)Employers are expected to inform job candidates of their status in the hiring process and communicate hiring decisions within the agreed-upon time frame.

If an employer is required by changing conditions to revoke a job offer that you've accepted, you're entitled to a fair and equitable course of action. That can include, but is not limited to, financial assistance and outplacement service.

NACE's Principles Committee encourages employers to:

- Reimburse candidates for expenses incurred in their acceptance of employment, such as travel and relocation expenses;

- $\quad$ Provide candidates with short-term financial assistance; and

- $\quad$ Provide services to aid candidates in securing other employment.

Job candidates should communicate acceptance or refusal of a job offer to employers as promptly as possible, so they can notify other candidates that the position is filled or that they are still being considered. When a job candidate accepts an offer, he/she should have every intention of honoring that commitment. Accepting an offer only as a precautionary measure is misleading to the employer and may restrict opportunities for others who are genuinely interested in that employer.. 
If candidates accept an offer or decide that full-time graduate or professional studies are for them, notify the career center and withdraw from the on-campus recruiting process immediately and inform employers that are actively considering them for a job that they are out of the running.

When an employer offers a job and the candidate accepts, a contract for employment at will has been created. The employer and the employee agree that the employer will provide work and the employee will show up to work. After the first day of work, either can end the relationship. If either changes his mind and revokes the agreement before employment begins, the legal question becomes, "What harm does the decision cause the other party?" .. . However, courts have not required an employer to hire someone after revoking a job offer, and generally employer have not been successful in suing a job candidate for reneging on an acceptance. In truth, an employer would have difficulty proving damages as a result of a candidate's reneging. In accepting the offer, the candidate agreed to work for an unspecified time; therefore revoking the agreement before the first day of work causes no legal harm to either party. . . Ultimately, this is an issue of good faith between employer and new employee. While there may be a moral commitment to an employment relationship, especially when a signing bonus is paid, creation of an enforceable employment contract based on an offer and acceptance is highly unlikely. Both employer and job candidate must rely on their ethical commitments to each other.

\section{AUTHOR INFORMATION}

Tom Brady is an Associate Professor in the Accounting Department at the University of Dayton. His teaching interests are in the areas of Financial Accounting and his research interests are in the areas of Financial, IFRSGAAP convergence and ethics in the accounting curriculum.

Ron Burrows is an Associate Professor and Chair of the Accounting Department at the University of Dayton. His teaching and research interests are in the area of Financial Accounting and the role of ethics in accounting education. Mike Geary is an Associate Professor in the Accounting Department at the University of Dayton. His teaching interests are in the areas of Financial Accounting and Auditing and his research interests are in the areas of Financial, Auditing and International Accounting.

\section{SUGGESTED RENEGE CASE SUMMARY GRADING RUBRIC}

\begin{tabular}{|l|l|l|l|}
\hline \multicolumn{1}{|c|}{$\begin{array}{c}\text { Suggested } \\
\text { Grading Criteria }\end{array}$} & \multicolumn{1}{c|}{ Not Good (1) } & \multicolumn{1}{c|}{ Good (2) } \\
\hline Identifies Dilemma & $\begin{array}{l}\text { Has a vague idea of what } \\
\text { the dilemma is and seems } \\
\text { uncertain as to what must be } \\
\text { decided }\end{array}$ & $\begin{array}{l}\text { Identifies the dilemma, } \\
\text { including pertinent facts \& } \\
\text { ascertains what must be } \\
\text { decided }\end{array}$ & $\begin{array}{l}\text { Describes the dilemma in detail } \\
\text { having gathered pertinent facts. } \\
\text { Ascertains exactly what must } \\
\text { be decided }\end{array}$ \\
\hline $\begin{array}{l}\text { Identifies \& Considers } \\
\text { Stakeholders }\end{array}$ & $\begin{array}{l}\text { Is unsure as to who should } \\
\text { be involved in or is affected } \\
\text { by the decision-making } \\
\text { process. Identifies a } \\
\text { minimal number of } \\
\text { stakeholders }\end{array}$ & $\begin{array}{l}\text { Determines who is affected by } \\
\text { or should be involved in the } \\
\text { decision-making process and } \\
\text { identifies most of the } \\
\text { stakeholders }\end{array}$ & $\begin{array}{l}\text { Determines who is affected by } \\
\text { and should be involved in the } \\
\text { decision-making process and } \\
\text { thoroughly reflects on the } \\
\text { interests of the stakeholders }\end{array}$ \\
\hline $\begin{array}{l}\text { Analyzes Alternatives \& } \\
\text { Considers Consequences }\end{array}$ & $\begin{array}{l}\text { Begins to appraise the } \\
\text { revant facts \& } \\
\text { assumptions and identifies } \\
\text { one/two alternatives }\end{array}$ & $\begin{array}{l}\text { Clarifies at least two } \\
\text { alternatives and } \\
\text { discusses/predicts their } \\
\text { associated consequences }\end{array}$ & $\begin{array}{l}\text { Clarifies a number of } \\
\text { alternatives and evaluates each } \\
\text { on the basis of how they } \\
\text { impact upon the interests and } \\
\text { welfare of all stakeholders }\end{array}$ \\
\hline $\begin{array}{l}\text { Proposes/Chooses } \\
\text { \& Supports an Action }\end{array}$ & $\begin{array}{l}\text { Fails to or has difficulty } \\
\text { identifying an appropriate } \\
\text { course of action from } \\
\text { among alternatives. }\end{array}$ & $\begin{array}{l}\text { Identifies a course of action; } \\
\text { formulates an implementation } \\
\text { plan and delineates the } \\
\text { execution of the decision }\end{array}$ & $\begin{array}{l}\text { Formulates an implementation } \\
\text { plan that delineates the } \\
\text { execution of the decision and } \\
\text { evidences thoughtful reflection } \\
\text { on the costs/benefits and risks } \\
\text { of action }\end{array}$ \\
\hline
\end{tabular}

Adapted from: AACSB International Assessment Seminar, Philadelphia, Pa. August 2008 \& the University of Scranton (http://academic.scranton.edu/department/assessment/ksom/ 